\title{
The western end of the Avalon Zone in southern New Brunswick
}

\author{
K.L. Currie \\ Geological Survey of Canada, 601 Booth Street, Ottawa, Ontario KIA OE8
}

Date Received March 25, 1988

Date Accepted August 26, 1988

\begin{abstract}
The westem end of the Avalon zone of southem New Brunswick displays a history extending from middle Proterozoic to Triassic time. About $620 \mathrm{Ma}$ magmatism above a Late Precambrian subduction zone emplaced volcanic rocks and plutons into an orthogneiss-platformal sequence basement which had becn modified by mafic intrusion and thermal metamorphism about 780 Ma. About $565 \mathrm{Ma}$ a bimodal shceted dyke complex accompanied by bimodal volcanism and high-level granite was emplaced into a major mylonite zone during minor spreading or transtension. Shallow water clastic marine sediments accumulated during Cambro-Ordovician time. From Silurian to mid-Devonian, the northwestem part of the zone subsided along steep faults which served as conduits for bimodal igncous activity. Strong Carboniferous deformation along the Bay of Fundy affected the interior of the terrane only slightly, if at all. Acadian and Taconic orogenies had little effect on this region, which acted as a relatively stable crystalline block during the Paleozoic. The exposed rocks may form a "welt" on continuous basement of similar character, which disappears north-westward beneath younger formations by down-stepping on faults, and south-eastward beneath overriding allochthons.
\end{abstract}

La terminaison occidentale de la zone d'Avalon au sud du Nouveau-Brunswick montre une histoire s'étalant du Protérozoïque moyen au Trias. Vers $620 \mathrm{Ma} \mathrm{le} \mathrm{magmatisme} \mathrm{au-dessus} \mathrm{d'une} \mathrm{zone} \mathrm{de} \mathrm{subduction} \mathrm{emplaça} \mathrm{des} \mathrm{roches} \mathrm{volcaniques}$ et des plutons dans un socle à orthogneiss et séquence de plate-forme qui avait été modifié vers 780 Ma par une intrusion mafique et un métamorphisme thermal. Vers $565 \mathrm{Ma}$ un complexe bimodal de "sheeted dikes", accompagné d'un volcanisme bimodal ct d'un granite de nivcau élevé, s'emplaça au sein d'une zone importante de mylonite au cours d'une faible expansion ou transtension. L'Ordovicien vit l'accumulation de sédiments clastiques d'eau peu profonde. Du Silurien au Dévonien moyen, la portion nord-ouest de la zone s'abaissa le long de failles à forts pendages qui agirent comme conduits pour une activité ignée bimodale. Une forte déformation carbonifere le long de la Baie de Fundy n'eût guère d'effet sur l'intérieur de la lanière. Les orogénèses acadienne et taconique n'eurent qu'un effet quelconque sur cette région qui forma un bloc cristallin relativement stable au cours du Paléozoïque. Les affleurements peuvent constituer un "renflement" sur un socle continu de même facture qui disparaît vers le nord-ouest sous les formations plus jeunes par abaissement sur des failles et vers le sud-est sous les allochtones chevauchants.

[Traduit par le joumal]

\section{INTRODUCTION}

Massifs of Late Precambrian volcanic and sedimentary rocks intruded by plutons of similar age, and locally overlain by Cambrian strata with an Acado-Baltic fauna, fringe much of the Atlantic coast of North America (Fig. 1). This assemblage of units constitutes an "Avalonian terrane" (compare Williams and Hatcher, 1983). The relations of these massifs with each other and with surrounding rocks remain obscure because of complex internal dissection by faults and disappearance of many of the critical boundaries beneath Devono-Carboniferous sedimentary basins. In particular, the nature of basement to Avalonian terranes and the extent of the terranes beneath surrounding younger rocks remain uncertain. The western end of the Caledonia block, an Avalonian terrane in southern New Brunswick (Fig.
2), exposes unequivocal basement to the late Precambrian rocks and contact relations with surrounding units which permit much of the Paleozoic tectonic history to be reconstructed. This region can, therefore, serve as a testing ground for a variety of theories on the origin and development of Avalonian terranes.

\section{DESCRIPTION OF UNITS}

The stratigraphy of the western part of the Caledonia block has been discussed in detail elsewhere (Helmsteadt, 1968; Garnett, 1973; Rast et al., 1976; Wardle, 1977; Donohoe, 1978; Ruitenberg et al., 1979; Currie et al., 1981; Currie and Nance, 1983; Currie, 1984, 1986, 1988; McCutcheon and Ruitenberg, 1987; Tanoli, 1987). The oldest rocks form a narrow rib of mesocratic, migmatitic quartz-plagioclase-hornblende \pm biotitc

Geological Survey of Canada Contribution Number 53287. 


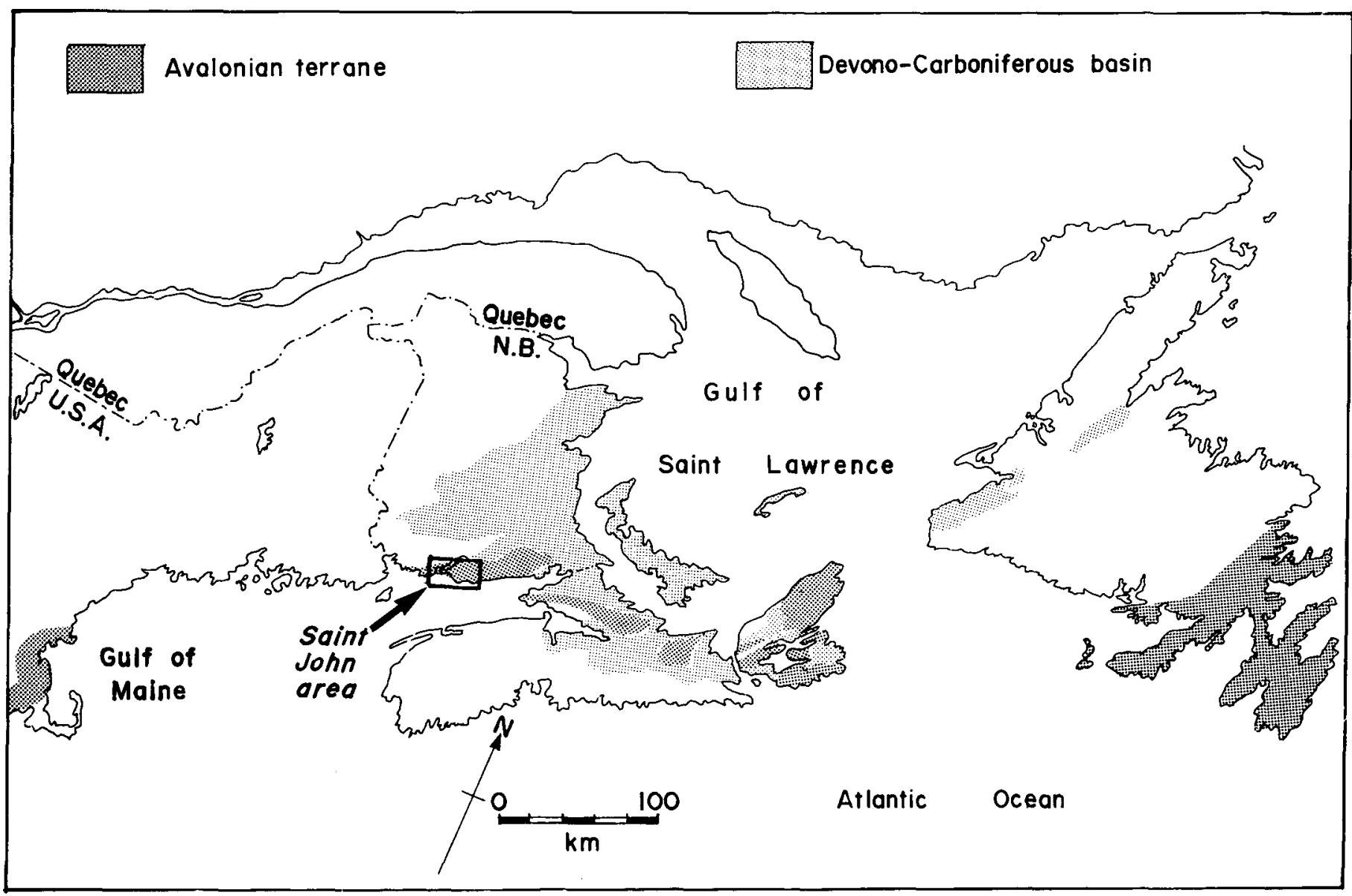

Fig. 1. Avalonian terranes in the northern Appalachians. The area covered by Figure 2 is marked with a box.

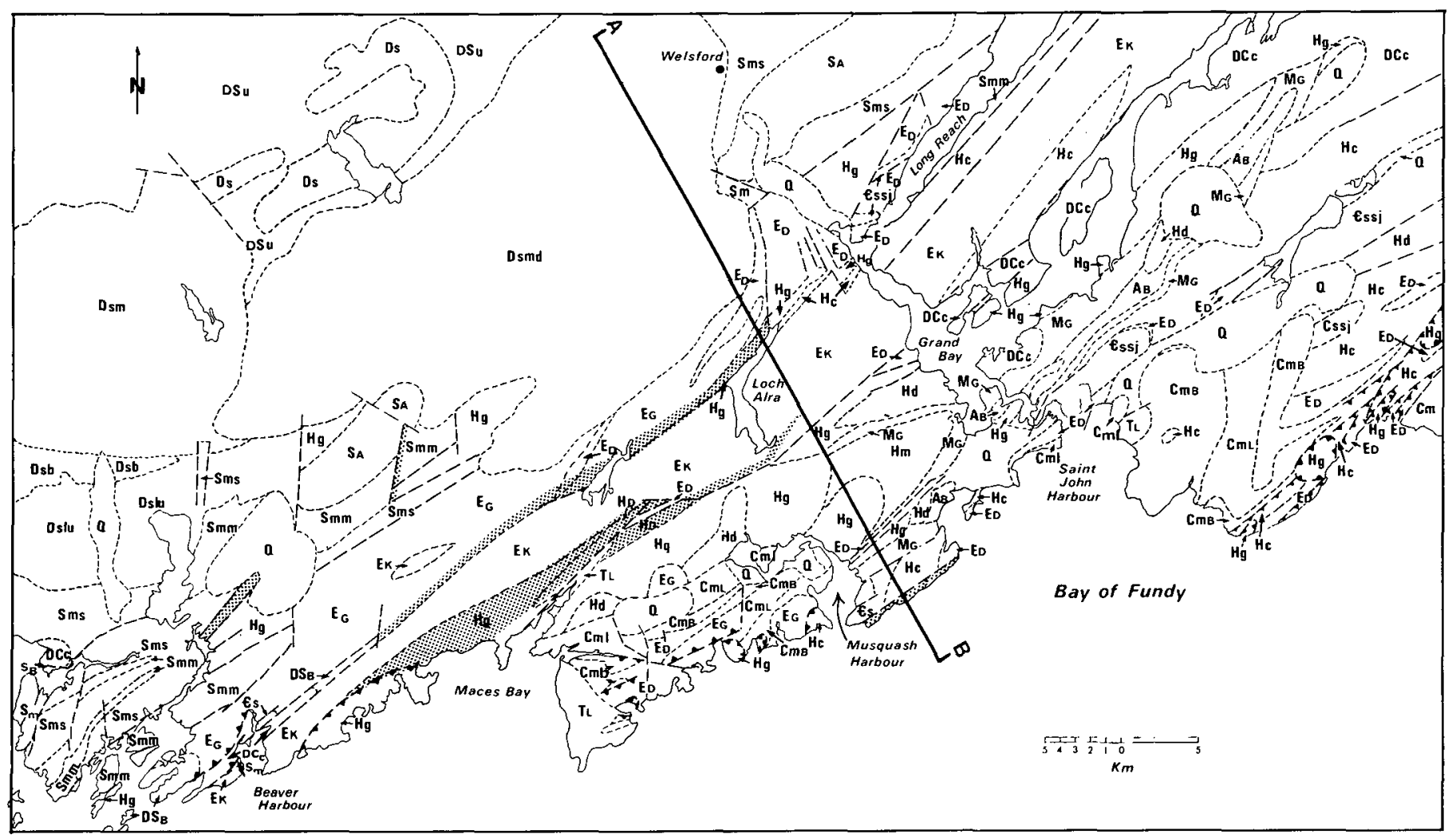

Fig. 2. Geological map of the western end of the Avalon terrane in southem New Brunswick. 
Lcgend for Figure 2

QUATERNARY

Q ill, moraine, outwash, glacio-marine deposits

TRIASSIC

$T_{L} \quad$ LEPREAU FM.; brown conglomerate, red sandstone and siltstone

LATE CARBONIFEROUS

$C_{M} \quad$ MISPEC GP.; LANCASTER FM. grey litharenite, pebble conglomerate, black siltstone (L); BALLS LAKE FM. red siltstone and shale with conglomerate lenses, basal caliche and limestone (B)

LATE DEVONIAN TO CARBONIFEROUS

$\mathrm{DC}_{\mathrm{c}}$ red conglomerate, green to tan sandstone with conglomerate lenses, includes KENNEBECASIS FM., PERRY FM., and BEAVER HARBOUR FM.

DEVONIAN

D SAINT GEORGE BATHOLTTH; MOUNT DOUGLAS PLUTON, biotite granite and porphyry with rapakivi feldspar, aplite dykes (md); pink seriate biotitc granite with tuffisite veins, LAKE UTOPIA PLUTON (lu) and MAGAGUADAVIC PLUTON (m); gabbro, diorite and granodiorite (BOCABEC COMPLEX (b))

$\mathrm{SD}_{\mathrm{u}} \quad$ undivided Silurian and Devonian strata north of the Saint George batholith, includes QUEEN BROOK FM., WAWEIG FM., and PISKAHEGAN GP.

LATE SILURIAN

$S_{A} \quad$ riebeckite granite, felsite, porphyry, aplitic amphibole granite, minor mafic phases. (WELSFORD and JAKE LEE MOUNTAIN plutons)

SILURIAN AND EARLY DEVONIAN

$S_{B} \quad$ BLACKS HARBOUR BEDS; deformed red conglomerate and siltstone (may be Late Devonian in part)

$S_{M}$ MASCARENE GP. (includes EASTPORT FM. equivalents); amygdaloidal basalt, tuff, thyolite, minor siltstone and limestone (m) (includes LONG REACH FM.); ryhthmically banded siltstone and shale, massive siltstone and sandstone, minor limestone, locally interbedded with volcanics (s) (includes JONES CREEK FM.)

CAMBRIAN AND LOWER ORDOVICIAN

$\mathrm{C}_{s} \quad$ SAINT JOHN GP., green sandstone and siltstone, basal red-beds and conglomerate, upper black shale (sj); BUCKMAN CREEK BEDS, basalt and thyolite flows and tuff, reddish siltstone and conglomerate $(\mathrm{bc})$

EOCAMBRIAN ( $565 \mathrm{Ma})$

$E_{D} \quad$ red feldspathic sandstone and tuff, conglomerate (s); ignimbrite, felsite and porphyry (f); basalt (b)

$\mathrm{E}_{\mathrm{G}} \quad$ red-stained granodiorite to granite, commonly leucocratic and aplitic; quartz-feldspar porphry (g); gabbro and melagabbro (u)

$\mathrm{E}_{\mathrm{k}} \quad \mathrm{KNNGSTON}$ COMPLEX, bimodal sheeted dykes, basalt, thyolite, foliated amphibolite and felsite; minor amounts of Coldbrook Group.

LATE PROTEROZOIC ( $-620 \mathrm{Ma})$

$\mathrm{Hg}$ GOLDEN GROVE SUTTE; homblende diorite(d), homblende-biotite granodiorite biotite granite, megacrystic granite. Rocks epidotized and chloritized, commonly with abundant enclaves and/or comingling textures.

$\mathrm{H}_{c} \quad$ COLDBROOK GP., mainly andesitic to thyolitic volcanic fragmental rocks, subordinate basaltic flows, minor conglomerate and thythmically banded grey siltstone and sandstone: equivalent mafic and salic schists

PROTEROZOIC ( 780 Ma)

$\mathrm{H}_{M} \quad$ MARTINON FM., black turbiditic siltstone with chenty lenses, minor debris flows, intercalated basaltic flows and sills

$P_{d} \quad$ tonalite, diorite, amphibolite, foliated and cut by numerous mafic dykes

MIDDLE PROTEROZOIC

$M_{G} \quad$ GREEN HEAD GP., marble, locally stromatolitic, quartzite, minor pelite

EARLY PROTEROZOIC (?)

$A_{8}$ BROOKVILLE GNEISS, dioritic to tonalitic gneiss and migmatite, commonly chloritized and mylonitized

geological contact

- fault, high angle or transcurrent

$\longrightarrow \rightarrow$ thrust fault, teeth on thrust block

mylonite zone

Geology after K.L. Currie, 1984, 1987, 1988; McCutcheon and Ruitenberg, 1987; M.J. McLeod and W.E. Gardiner, personal communication. 
gneiss (Brookville gneiss, unit $A_{B}$ on Fig. 2) diapirically emplaced into its surroundings as a plastic solid (Currie et al., 1981). The Green Head Group (unit $M_{G}$ ) of buff to grey, locally stromatolitic, marble, quartzite and minor pelitic schist was mobilized along the contact with the Brookville gneiss, complexly structurally interleaved with it, and raised from chlorite to sillimanite grade (Wardle, 1977). The age of gneiss emplacement with its high temperature deformation and attendant deformed mafic dyke swarm (Fig. 3) appears to be fixed by $780-820$ $\mathrm{MaPb}-\mathrm{U}$ ages on zircon from deformed dioritic gneiss (Olszewski and Gaudette, 1982). The protolith ages remain uncertain. Hofmann (1974) estimated an age of 1000-1500 Ma for stromatolites of the Green Head Group.

Turbiditic siltstones and debris flows of the Martinon Formation (unit $\mathrm{H}_{\mathrm{M}}$ ) rest unconformably on the Green Head Group (Fig. 4) west of Grand Bay. The Martinon Formation, which contains a significant component of basalt sills and flows, occurs mainly as cuspate synformal enclaves between large plutons, for one of which Olszewski et al., (1980) reported an age of $615 \mathrm{Ma}$ by $\mathrm{Rb}-\mathrm{Sr}$ isochron. The age of the Martinon Formation remains uncertain. S.R. McCutcheon (personal communication, 1988) pointed out that the lithology and stratigraphy resemble those of the Burin Group of Newfoundland which has been dated at 762 Ma (Krogh et al., 1988).

The calc-alkaline, arc-related (Fig. 5, see also McCutcheon in Ruitenberg et al., 1979) Coldbrook Group (unit $\mathrm{H}_{c}$ ) in the Saint John area consists of abundant intermediate, commonly fragmental volcanic rocks, including lahars and ignimbrites, subordinate basaltic flows, locally pillowed, and minor sedimentary rocks, mainly rhythmically banded siltstones, with minor conglomerate and sandstone. A suite of elongate dioritic to grano- dioritic I-type plutons (Golden Grove suite, unit $\mathrm{H}_{\mathrm{g}}$, Hayes and Howell, 1937) may be cogenetic with the Coldbrook Group, although the two units are rarely seen in close proximity except across faults. Golden Grove plutons typically exhibit cognate enclaves of felsic and mafic rocks with textures varying from netveining and agmatitic, to spectacular mixing textures. Watters (1987) reported a preliminary $\mathrm{Pb}-\mathrm{U}$ age on zircon of $625 \pm 15 \mathrm{Ma}$ for the pluton at Cape Spenser. Stukas (1978) reported similar ages for volcanic rocks south of the Long Reach (630-640 Ma by ${ }^{40} \mathrm{Ar} /{ }^{39} \mathrm{Ar}$ ). Rocks of the Coldbrook Group, Golden Grove suite and Martinon Formation exhibit a pervasive prehnite-pumpellyite to greenschist facies metamorphism.

The youngest Precambrian rocks in southern New Brunswick comprise a bimodal sheeted dyke complex (Kingston complex, unit $E_{k}$ ), high-level granitoid plutons (unit $E_{G}$ ), and a bimodal volcanic-red bed suite (unit $E_{b}$ ). The Kingston complex, with a strike length of more than $100 \mathrm{~km}$ and a width of 3 to $6 \mathrm{~km}$, consists mainly of alternating salic and mafic dykes (Fig. 6). The central part of the complex is at greenschist facies (Leger, 1986) but the grade declines toward the margins, which are marked by major mylonite zones. Relict igneous textures persist through much of the complex. Leucocratic, equigranular red granodiorite to monzogranite bodies (unit $\mathrm{E}_{\mathrm{G}}$ ) characterized by strong radiometric signature (Shives, 1986) form lenticles within the Kingston complex and equant plutons outside it. Two of these bodies gave $\mathrm{Pb}-\mathrm{U}$ zircon ages of $565 \pm 8 \mathrm{Ma}$ (Currie, 1987, 1988). Red tuffaceous siltstone and conglomerate associated with basalt and rhyolite porphyry flows (unit $E_{D}$ ) occur north of the Kingston complex and also along the Fundy coast. The basalts chemically resemble the Coldbrook Group, but show some transition toward within-plate chemistry (Fig. 5). These strata underlie the Cam-

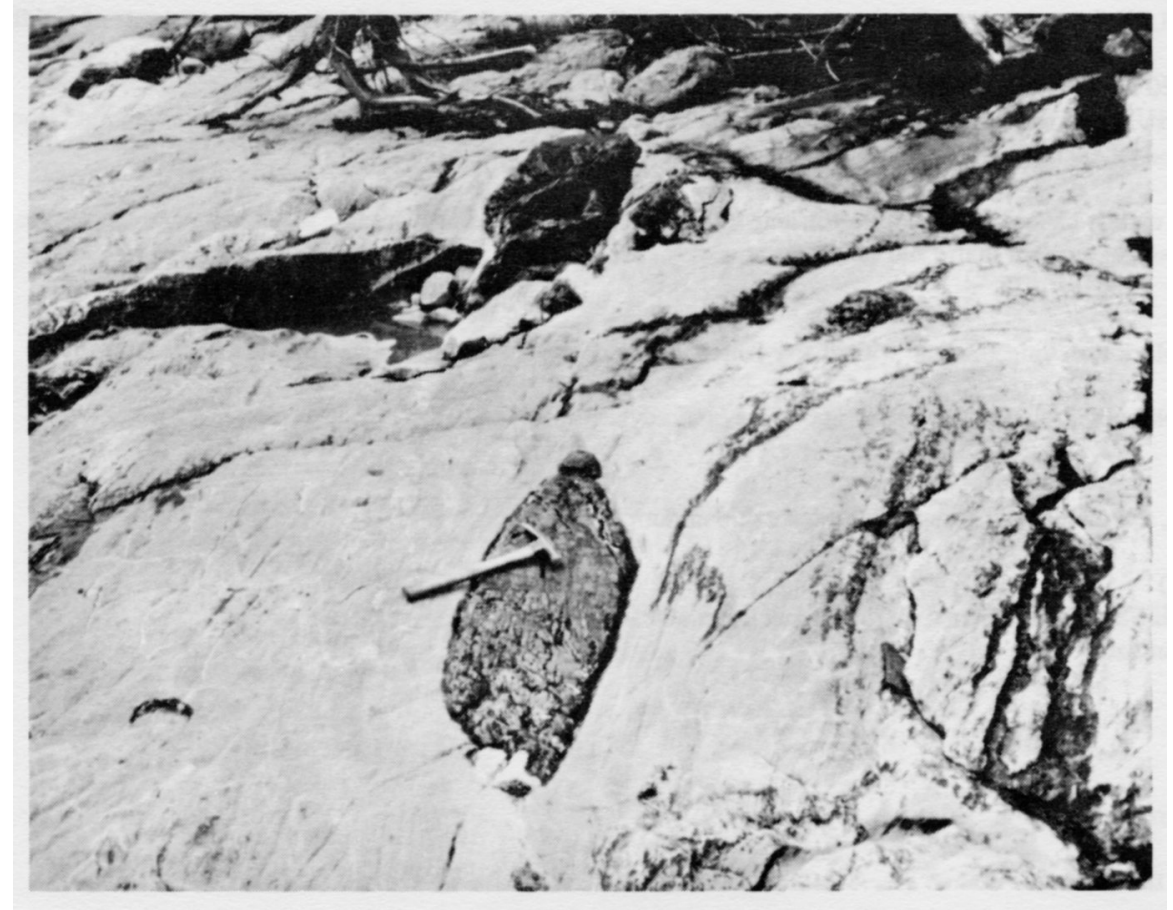

Fig. 3. Mafic dyke dismembered by mobilized Green Head marble, shore of Musquash Harbour. Note rootless isoclinal fold in marble. Hammer is $35 \mathrm{~cm}$ long. 


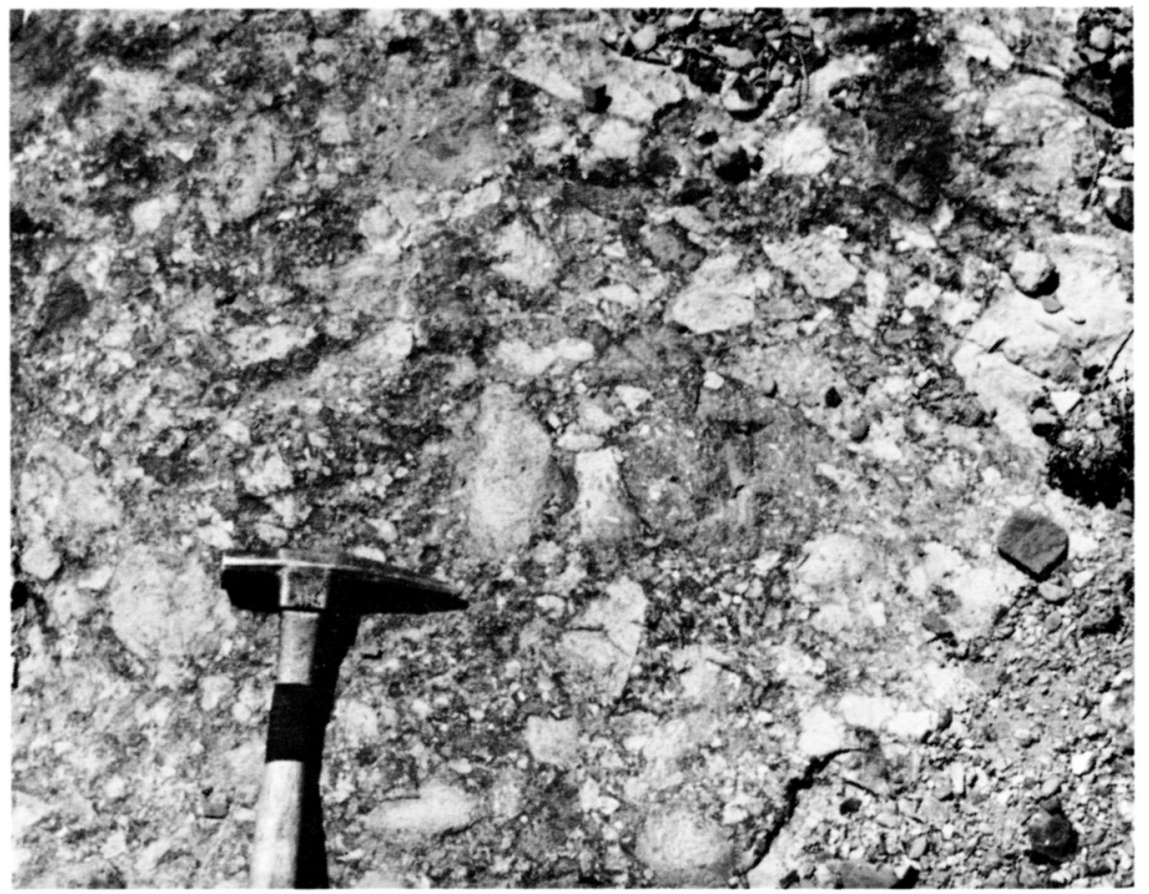

Fig. 4. Proximal debris flow in Martinon Formation, southeast of Grand Bay, with clasts derived almost entirely from marble of the Green Head Group. Note the cuspate shapes of clasts resulting from pressure solution effects. Hammer is $35 \mathrm{~cm}$ long.

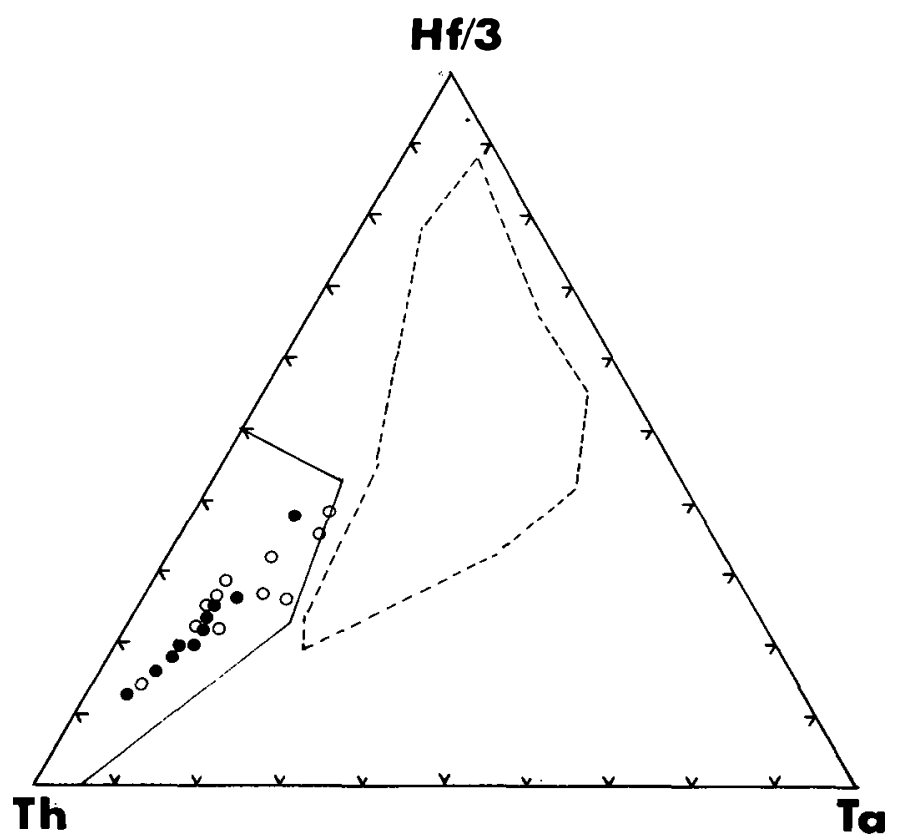

Fig. 5. Th-Hf-Ta data for volcanic rocks of the Coldbrook Groups and Eocambrian strata. Solid circles - Coldbrook Group; open circles Eocambrian strata. Field enclosed in solid line corresponds to calcalkaline rocks from destructive plate margins (Wood, 1980). Note that both Coldbrook and Eocambrian volcanics are calc-alkaline, but the latter are displaced toward the MORB field (dashed line). INAA data from samples collected and analysed by G.N. Eby. brian Saint John Group with only slight angular discordance, suggesting that the Eocambrian rocks and the basal Cambrian Ratcliffe Brook Formation of the Saint John Group may form a single stratigraphic "package."

Two types of Lower Cambrian to Lower Ordovician strata (unit $\mathrm{C}_{\mathrm{s}}$ ) occur. The Saint John Group, a transgressive barrier-bar complex of sandstone and siltstone (Tanoli, 1987) lies unconformably upon the Coldbrook Group. It now appears mainly in down-dropped fault slices. At the head of Beaver Harbour a sequence of ignimbrite, vesicular basalt, lapilli tuff, tuffaceous siltstone and calcareous siltstone capped by red siltstone with volcanic cobbles rests unconformably on the Kingston complex and an Eocanbrian(?) granite. The lapilli tuff yielded middle Cambrian (P. benneti zone) fossils (Helmsteadt, 1968). Thin tuffaceous beds in the Saint John Group may be equivalent to this volcanic sequence.

Silurian to Devonian sedimentary and volcanic strata fringe the northwestem margin of the Precambrian rocks. The upper part of this sequence in the Passamaquoddy Bay area has generally been correlated with the Eastport Formation of Maine (Pickerill et al., 1978; Donohoe, 1978; Van Wagoner and Faye, 1988), but stratigraphy and nomenclature of lower strata ("Mascarene Group") remain unresolved. Northeast of the Mount Douglas pluton (Fig. 2, Unit $\mathrm{D}_{\text {smd }}$ ) McCutcheon and Boucot (1984) considered basalt, tuff and siltstone of the Long Reach Formation to be conformably overlain by siltstone of the Jones Creek Formation. As Llandovery fossils occur in the former and Pridolian fossils in the latter, the two formations span 


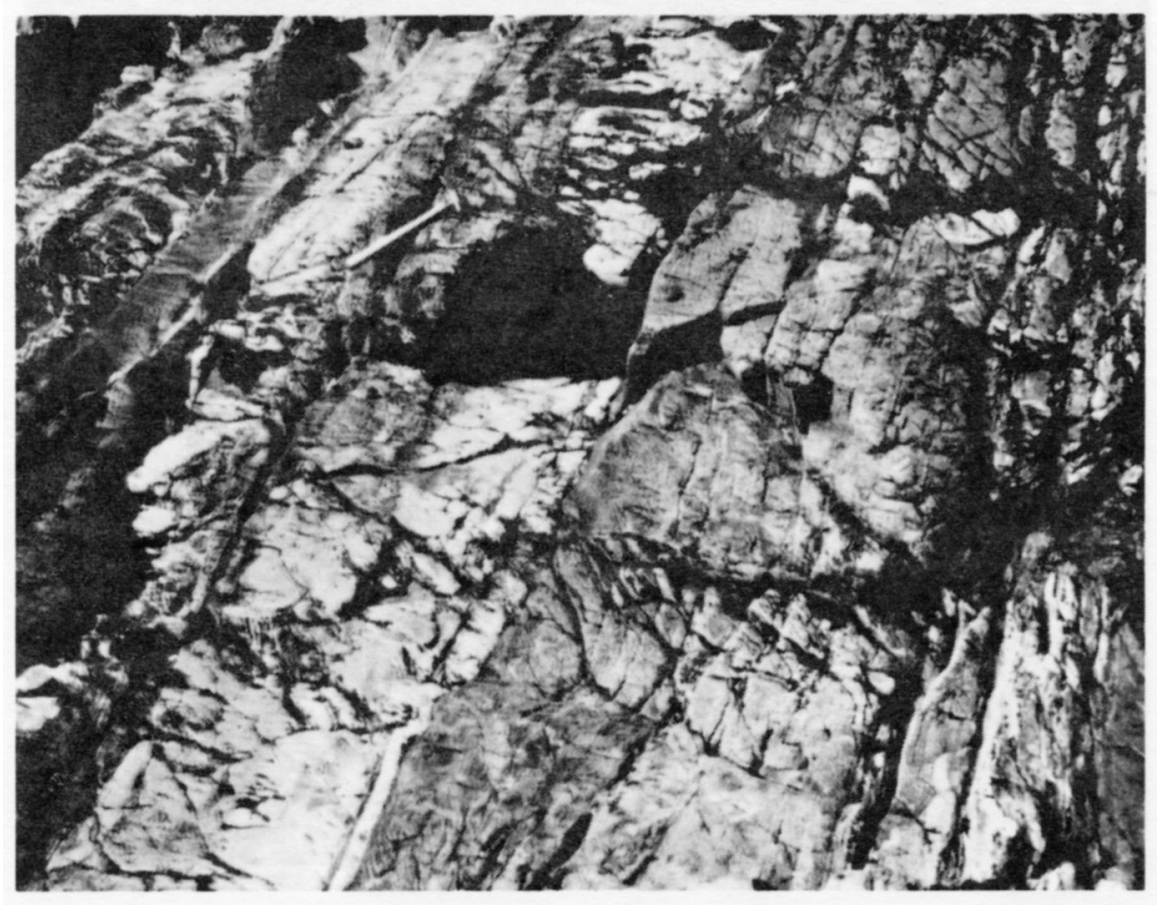

Fig. 6. Sheeted bimodal dykes, Kingston complex, Beaver Harbour. Hammer at centre left is $35 \mathrm{~cm}$ long.

Wenlock and Ludlow time. Currie (1987) found basalt and siltstone interbedded northwest of Grand Bay, suggesting that relations between the Long Reach and Jones Creek formations may be more complex than envisaged by McCutcheon and Boucot (1984). Southwest of the Mount Douglas pluton a shallow marine-littoral Silurian section, Llandovery in age at the base, faces consistently to the northwest (Donohoe, 1978), and passes north into interbedded sedimentary and volcanic rocks that are Pridolian near the top, or even of Gedinnian age (Van Wagoner and Faye, 1988). Unconformity between Silurian and Precambrian rocks has not been directly observed, but abundance of dykes in the Precambrian granites and granitic cobbles in the Silurian volcanic rocks (Fig. 7) prove a hidden unconformity.

The "Saint George batholith" comprises five plutons of Silurian to Devonian age. High level alkaline to peralkaline granite (unit $S_{A}$ ) occurs in a linear belt which is interrupted by the Mount Douglas pluton. Volcanic strata correlative to the granite form part of the Pridolian Jones Creek Formation (Payette and Martin, 1987). The early Devonian Bocabec complex comprises sheets of gabbro grading to granodiorite and has yielded a $\mathrm{Rb}-\mathrm{Sr}$ isochron age of $403 \mathrm{Ma}$. The Lake Utopia and Magaguadavic plutons consist of coarse biotite granite of Middle Devonian ( $380 \mathrm{Ma})$ age. Late Devonian coarse-grained to megacrystic biotite granite of the Mount Douglas pluton (360-370 Ma by ${ }^{40} \mathrm{Ar}$ ${ }^{39} \mathrm{Ar}$, M.J. McLeod, 1987, personal communication, 1988) has cut all older units. The Mount Douglas pluton intruded both Silurian strata and Precambrian granite on its south side. Gravity modelling by Thomas and Willis (in press) suggests that the Bocabec complex is a thin sill, not more than a few hundred metres thick, whereas the granitic rocks of the Lake Utopia, Magaguadavic and Mount Douglas plutons form a sheet some 6 $\mathrm{km}$ thick overlying Paleozoic strata and possibly Precambrian basement. The lack of minor intrusions around the south side of the Saint George batholith is striking. Only the Eagle Lake stock (Ruitenberg, 1969) may be correlative.

Carboniferous strata northwest of the Kingston complex comprise little deformed red sandstone and conglomerate of the Kennebecasis, Perry and Beaver Harbour formations (units $\mathrm{DC}_{\mathrm{c}}$ ) which are locally derived clastic sequences deposited in fault troughs. The lower parts of these formations are Late Devonian in age (Hayes and Howell, 1937; Alcock and Perry, 1960), whereas the upper parts may be as young as Westphalian (Currie, 1984). The Blacks Harbour member of the Perry Formation, as defined by Schluger (1973), consists of deformed red siltstonesandstone sequences with abundant caliche horizons and coarse conglomerate intervals which occur in several fault troughs southeast of the Mascarene Group. Alcock and Perry (1960) considered the Perry Formation to be little deformed and to contain debris of Devonian granites. The beds in question obey neither criterion, do not correlate well with the rest of the Perry Formation, and may be significantly older, possibly lower Devonian to upper Silurian in age and equivalent to part of the upper Mascarene Group. The rocks are shown separately on the map under the name Blacks Harbour beds at the suggestion of N. Rast (personal communication, 1988).

Southeast of the Kingston complex, the Mispec Group (in the sense of Currie and Nance, 1983) represents an alluvial fan complex fed from the southeast (unit $C_{M}$ ). The lower (proximal) Balls Lake formation, resting unconformably on Coldbrook and Saint John Groups and Golden Grove suite, consists of red siltstone with conglomerate lenses, and basal caliche-rich layers with a local basal, black stromatolitic limestone. The upper (distal) Lancaster Formation consists of pale grey lithic arenite with thin black, plant-bearing, siltstone layers. The Mispec 


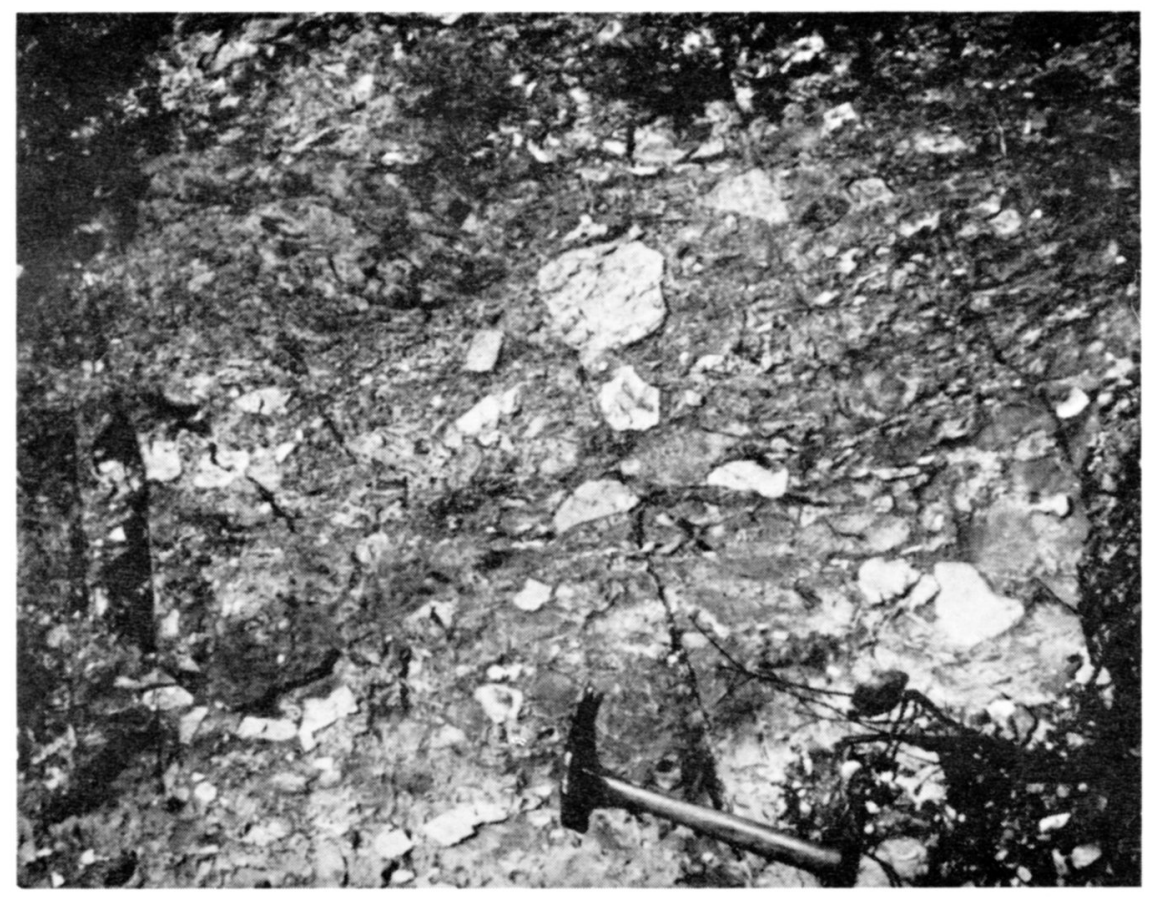

Fig. 7. Mafic volcanic of the Mascarene Group packed with granite debris, woods road $18 \mathrm{~km}$ north of Beaver Harbour. Hammer is $35 \mathrm{~cm}$ long.

Group is mainly of Westphalian age, although the range in age may be from Visean to Stephanian (Currie and Nance, 1983).

Chocolate-coloured conglomerate and red siltstone of the Triassic Lepreau Formation (unit $T_{L}$ ) occur in several small, fault bounded troughs along the Bay of Fundy. A large thickness of Triassic rocks has been detected by oil exploration just off-shore in the Bay of Fundy.

\section{DEFORMATION OF THE WESTERN END OF THE AVALON ZONE}

The structures of the rocks of the western part of the Avalonian terrane have been the subject of much work by students and staff at the University of New Brunswick (Helmsteadt, 1968; Garnett, 1973; Brown, 1972; Rast and Grant, 1974; O'Brien, 1976; Wardle, 1977; Rast et al., 1978; Donohoe, 1978; Parker, 1984; Leger, 1986), and by Ruitenberg and co-workers for the New Brunswick Geological Survey (Ruitenberg et al., 1973; Ruitenberg et al., 1977; Ruitenberg and McCutcheon, 1982). Interpretation of observations made in these studies has proven quite controversial because of difficulty in establishing the age of deformation and correlating these ages from one fault panel to another.

Regionally developed, systematic folding has proved difficult to detect. In the Saint John area pre-Coldbrook ductile deformation of the Brookville gneiss and Green Head Group (Fig. 3) cannot reliably be distinguished from younger deformation (Nance, 1982), although relations between Brookville gneiss and Green Head Group prove at least some deformation about $780 \mathrm{Ma}$. Late Precambrian deformation of the Coldbrook Group and older rocks has not been proved on a regional scale ( $\mathrm{O}^{\prime} \mathrm{Brien}$, 1976; Wardle, 1977), although deformation about $620 \mathrm{Ma}$ is demonstrated where the Martinon Formation occurs as hornfelsed and migmatised synclinal keels between dated plutons.

Traditionally most folding was assigned to the Ordovician Taconian and Siluro-Devonian Acadian orogenies (Helmsteadt, 1968; Garnett, 1973; Wardle, 1977; Donohoe, 1978; Ruitenberg et al., 1979), although the evidence was at best slender and circumstantial (see Wardle (1977) for a careful discussion). Since the pioneering work of Rast and Grant (1974) and Rast $e t$ al. (1978), most workers assign a Carboniferous age to strong folding and thrusting along the Bay of Fundy (Currie and Nance, 1983; Parker, 1984; Nance and Warner, 1986; Caudill and Nance, 1986; Watters, 1987). Major folding of the Saint John Group resembles folds in nearby Carboniferous rocks in style and orientation (Currie, 1984). Minor folds in fault slivers of the Saint John Group appear to be related to faults (Wardle, 1977) known to exhibit Carboniferous movement. No metamorphism or plutonism of Taconian or Acadian age can be demonstrated south of the Kingston complex (Currie, 1984, 1986). Radiometric ages quoted by Helmsteadt (1968) and Stukas (1978) in support of an Acadian event suffered both from inherent unreliability ( $\mathrm{K} / \mathrm{Ar}$ on actinolite and $\mathrm{Ar} / \mathrm{Ar}$ on plagioclase) and poor internal consistency.

Donohoe (1978) described polyphase Acadian folds and cleavage in the Saint George area. He also noted that the Silurian section has a consistent northwesterly facing direction. These observations are probably better explained by local fault-related deformation, rather than large-scale systematic folding. Penetrative cleavage of several ages occurs across the belt, but the trends of these cleavages are diverse. In many cases the cleavage is demonstrably of Carboniferous or younger age, for example where it cuts Carboniferous rocks. In some cases a Precambrian age can be demonstrated, for example where uncleaved Cam- 
brian rocks sit unconformably on the Kingston complex.

Numerous northeast-, north- and northwest-trending faults cut the terrane. Indeed it would hardly be an exaggeration to describe the whole region between the Long Reach and the Bay of Fundy as a high-strain zone. Most recognizable faults belong to one of four groups, namely (a) old ductile faults (mylonite zones), (b) steeply-dipping northeast-trending brittle faults, (c) steeply-dipping north- to northwest-trending brittle faults, (d) gently to moderately south-or north-dipping brittle-ductile faults.

Old mylonite zones fringe both sides of the Kingston complex from Beaver Harbour to Loch Alva. Mylonitization is intense in granitoid rocks (Fig. 8) but weak or absent in mafic dykes of the Kingston complex, which locally cut the mylonite at a high angle (Fig. 9). The mylonites nowhere cut Phanerozoic strata, but a sliver of unmylonitized fossiliferous Silurian rocks has been downdropped into mylonitic granite on New River. Greenschist-facies metamorphism affects dykes, mylonites and granites, but not overlying Cambrian strata. Stratigraphic evidence strongly suggests that mylonitization occurred in late Precambrian time. The mylonite zones end abruptly at Loch Alva.

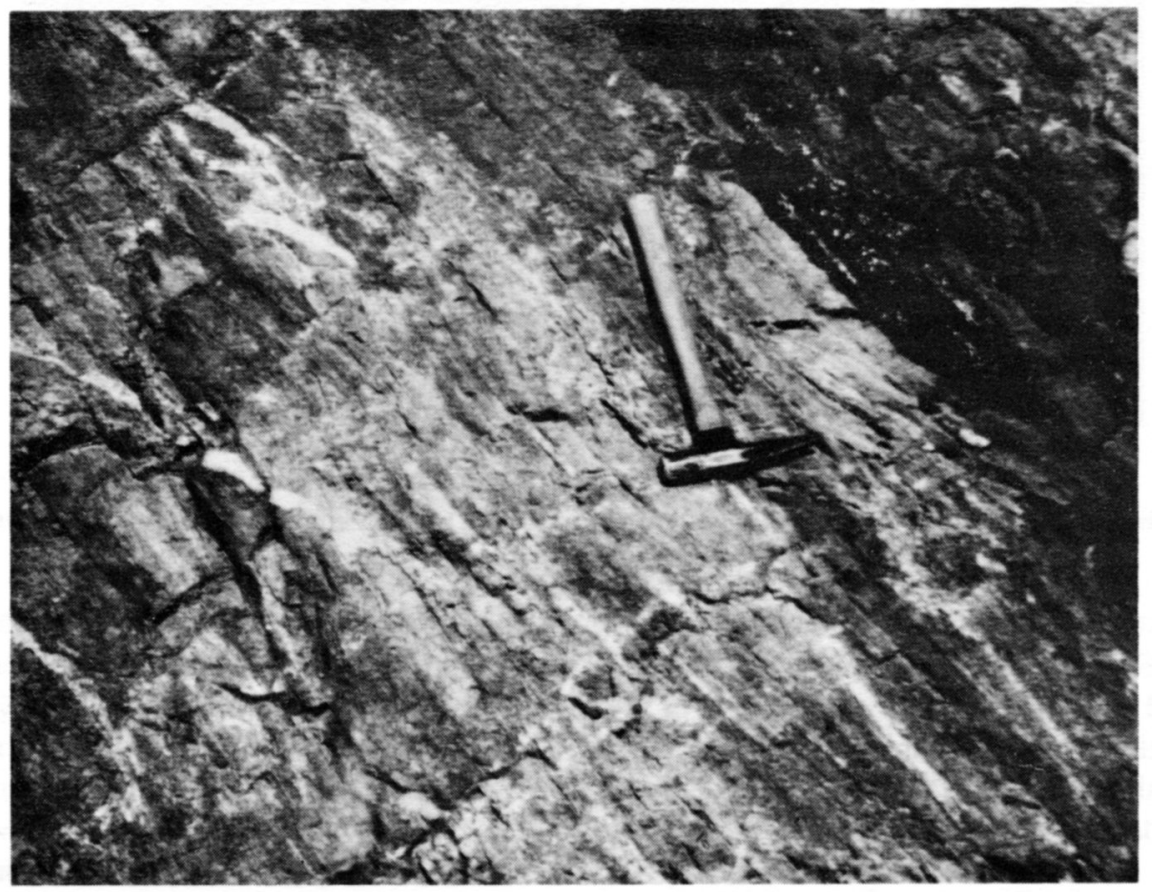

Fig. 8. Mylonitic granite, gravel pit near Lepreau. Note the mylonitic banding and horsetailing of the host. Hammer is $35 \mathrm{~cm}$ long.

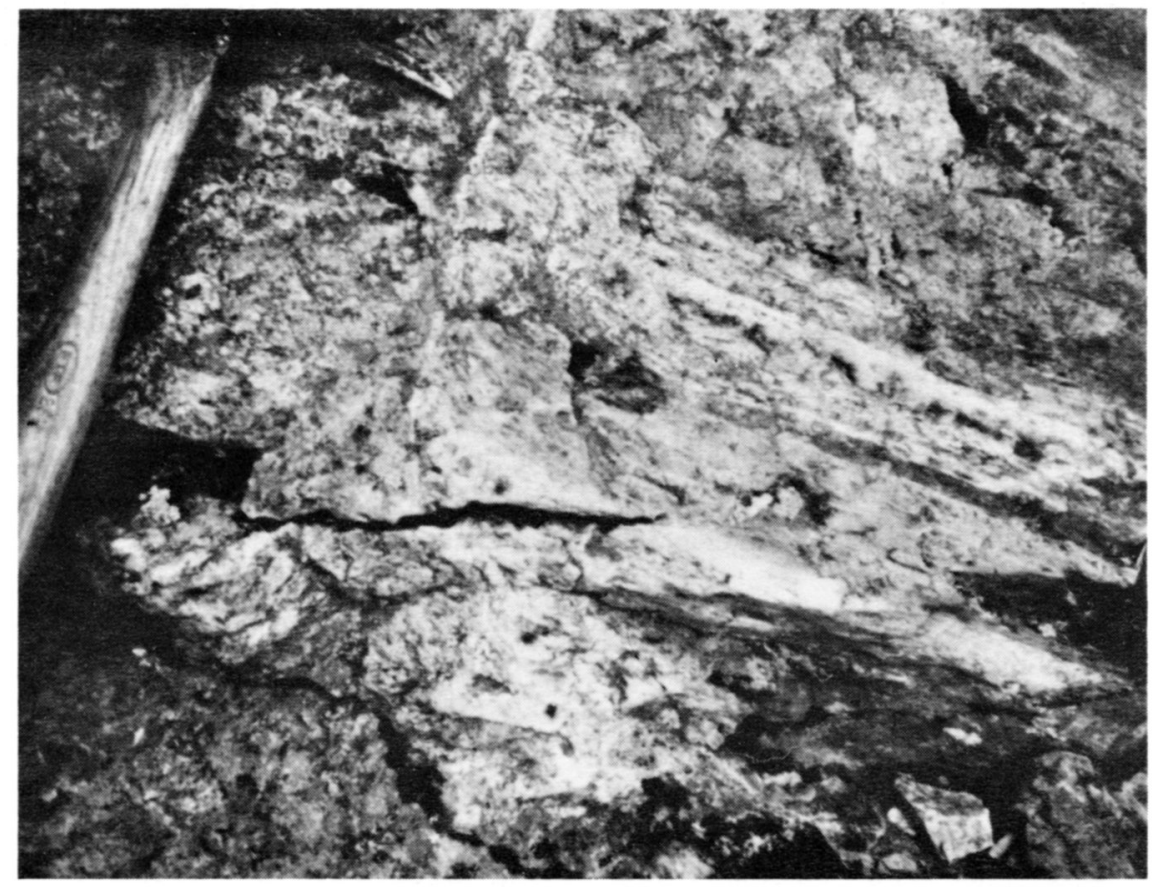

Fig. 9. Mylonitic granite cut by little deformed dyke of the Kingston complex. The contact is marked by a narrow white contact aureole at the hammer point. Same locality as Figure 8. 
Most kinematic indicators suggest dextral motion in the mylonite zones (Leger, 1986), but small-scale sinistral indicators occur locally within the Kingston complex. The mylonite zone and Kingston complex both exhibit a very consistent, northeasttrending, steeply plunging lineation. The scale of motion is uncertain because there are no precise markers of appropriate age. However plutons of identical age and petrography occur on opposite sides of the zones. Shearing appears to have dissected a magmatic suite, rather than juxtaposing unrelated suites. Movement, therefore, appears likely to have been in the tens, rather than thousands, of kilometres. Garnett and Brown (1973) and Rast and Currie (1976) showed that the mylonite zone on the north side of the complex does not mark the northwestern boundary of Precambrian rocks (Fig. 10), and this point has been emphasized by recent $\mathrm{Pb}-\mathrm{U}$ zircon age determinations which demonstrate that late Precambrian granite extends up to the Mount Douglas pluton (Currie, 1988).

Steeply dipping northeast-trending brittle faults tend to follow the older mylonite zones, but locally cut them at a low angle. East of Loch Alva where the mylonite zones are absent or inconspicuous, the faults form anastamosing breccia zones following the margins of the Kingston complex, and including outof-sequence fault blocks. In some cases latest motion on these faults can be dated by emplacement of undeformed igneous rocks across the faults. These data indicate a considerable range of ages from early Silurian to Mississippian. Geophysical modelling suggests significant high-angle displacement on some of these faults (Thomas and Willis, in press; Spector and Pichette, 1980). A northwest-side down motion totalling nearly $11 \mathrm{~km}$ has been deduced beneath the Mount Douglas pluton. Farther south, Helmsteadt (1968) and Garnett (1973) deduced only small displacements of a few tens of meters in Phanerozoic time, producing small grabens. To the southeast, Gupta (1975) deduced a kilometre-scale down-drop of the southeastern side on the Green Head-Coldbrook boundary. This pattern suggests systematic uplift of the exposed Avalonian rocks relative to their surroundings.
Little detailed work has been done on the north- to northwest trending features. The Oak Bay fault west of the mapped area shows late sinistral movement (Stringer, 1982). A series of small-scale exposed faults northwest of Grand Bay show alternating sinistral and dextral motions with a significant normal component. A very strong linear feature parallel to these faults runs from Grand Bay to Welsford. The orientation of this lineament relative to the northeast-trending structures suggests a Riedel shear pattern. The dominant northeast-trending shear zones are thought to be dextral (Leger, 1986). Therefore sinistral motion is predicted on the Grand Bay lineament, and overall eastwest compression. A very strong north-trending lineament runs from the north end of Loch Alva to Welsford. Major mylonite zones end abruptly against this lineament. Perhaps the Loch Alva-Welsford-Grand Bay triangle represents some kind of gigantic kink band.

Moderate- to low-angle faults occur along the Bay of Fundy. This Carboniferous deformation has been extensively described (Rast and Grant, 1974; Rast et al., 1978; Currie and Nance, 1983; Parker, 1984; Nance and Warner, 1986; Watters, 1987). For the present purpose it suffices to note that whatever the significance of the deformation off-shore, it affects only a thin skin of the Avalon terrane on-shore. Along the Bay of Fundy, older mylonite zones have been partially overprinted by Carboniferous deformation (Rast and Dickson, 1982), but this effect extends only a few kilometers inland. Similarly Triassic extension, presumably related to opening of the Atlantic Ocean may truncate the Avalon zone offshore, but onshore produces only minor grabens.

\section{STRUCTURAL SYNTHESIS}

The termination of the Avalon terrane in southern New Brunswick can be understood in semi-quantitative fashion from recent mapping and geophysical results. The oldest configuration deducible from present evidence (Fig. 11a) has the metasedimentary shelf-type sequence of the Green Head Group resting on

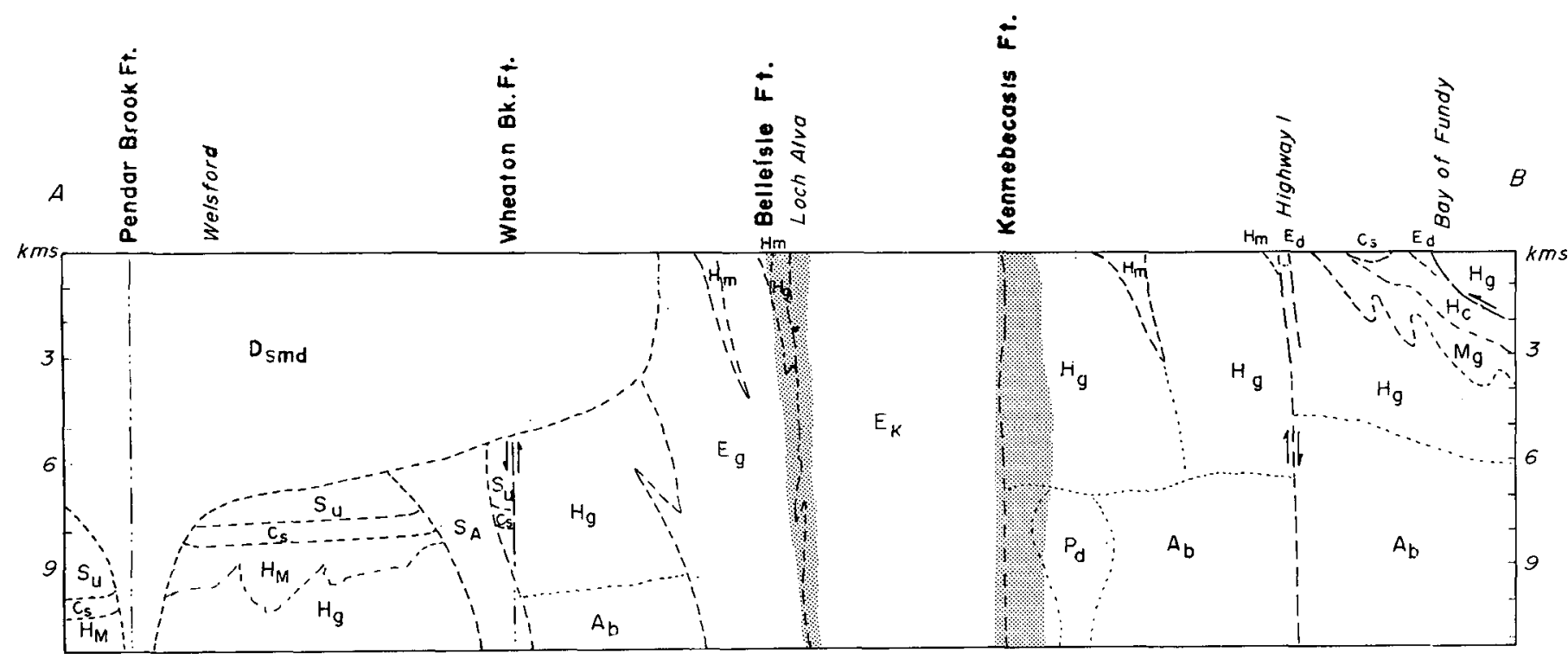

Fig. 10. Partly schematic cross-section across the Avalon zone in southern New Brunswick. The legend is the same as Figure 2. Vertical and horizontal scales are the same. Data beneath the Mount Douglas batholith from Thomas and Willis (in press). 

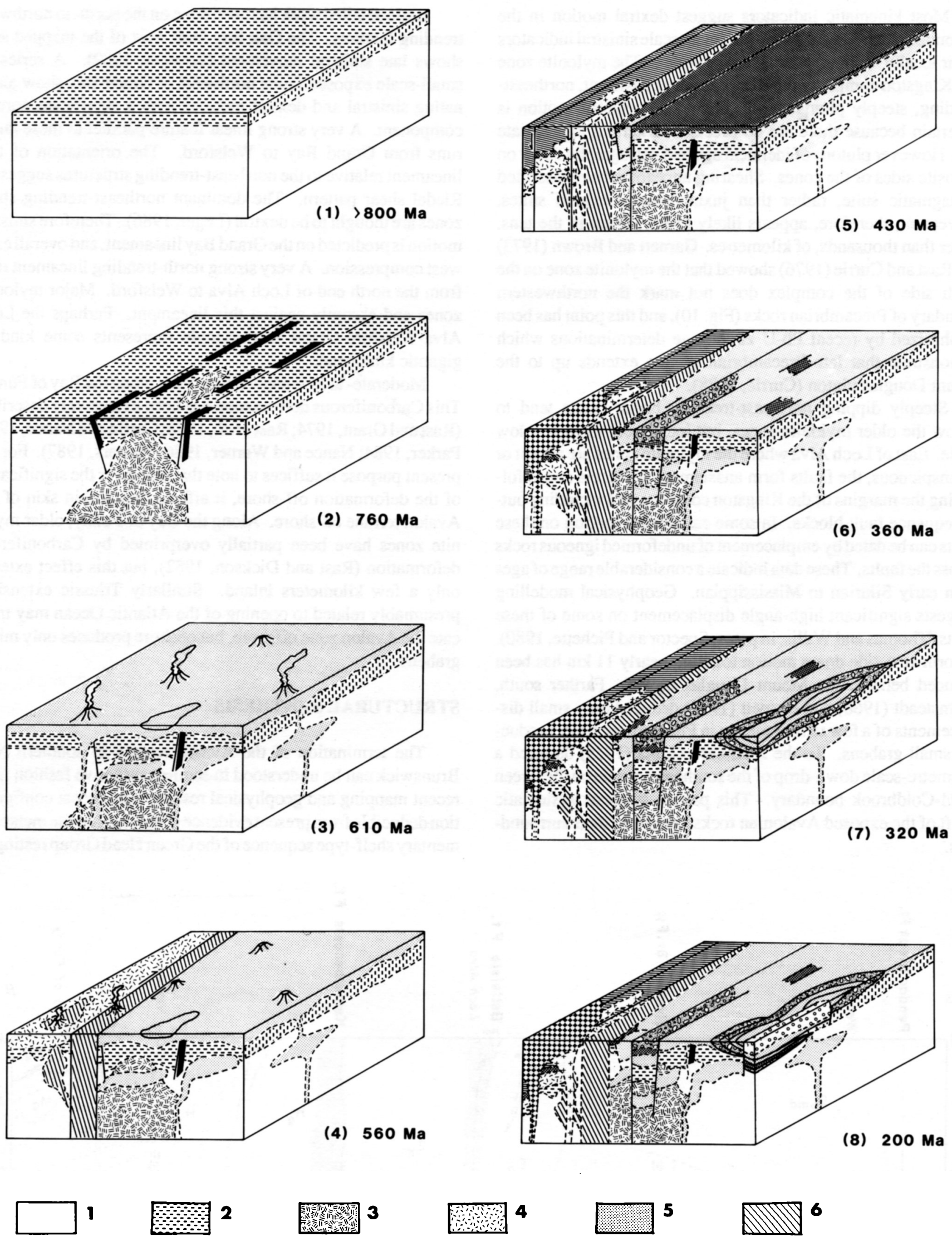

(8) $200 \mathrm{Ma}$
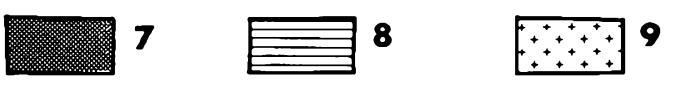
Brookville gneiss. Like other similar sequences in the Cobequid Highlands (Bass River complex, Gaudette et al., 1983) and Cape Breton Island (George River Group, Lowland Brook syenite (Barr et al., 1987)) the lithologies and age constraints are suggestive of the Grenville province of the Canadian Shield. About 780 Ma (Fig. 11b) emplacement of dioritic plutons and mafic dykes was accompanied by high-temperature, low-pressure metamorphism. High-temperature, low-pressure metamorphism in Cape Breton Island (Jamieson, 1984) has been dated at $701 \mathrm{Ma}$ (Gaudette et al., 1985). Gabbro of oceanic affinity in Newfoundland (Strong and Dostal, 1980) gave an age of $762 \mathrm{Ma}$ (Krogh et al., 1988). The significance of these ages is not understood at present, but a tensional event with upwelling of mafic magma, possibly locally generating oceanic crust seems reasonable. About $620 \mathrm{Ma}$ (Fig. 11c) subduction-related arc volcanism emplaced the Coldbrook Group and associated plutons. Northwest-directed subduction could have built an arc on Grenville basement, but microcontinents left after an earlier event, as envisaged for example by O'Brien et al. (1983), would do as well. Presence of a Pan-African event on Canadian shores (O'Brien et al., 1983) is not surprising as the continents were assembled at this time and Africa probably juxtaposed with Atlantic Canada (Worsley et al., 1984).

Before $565 \mathrm{Ma}$ (Fig. 11d) transcurrent motion, possibly the result of oblique convergence, developed the mylonite zones typical of the western Caledonia block. A tensional phase indicated by emplacement of the dyke complex generally postdated shearing, and may have marked the opening of the "Iapetus Ocean" as suggested by Rast (1979).

During Cambrian and Ordovician time, the western Caledonia block was a rigid, relatively high-standing region, but by early Silurian time (Fig. 11e) the northwestern part of the block began to subside along faults. These brittle faults roughly paralleled nearby older ductile shear zones, but in most cases the trends and positions of the two types of faults can readily be distinguished. Both mafic, mantle-derived magma and salic magma with a large crustal component, as indicated by isotope signature (Bevier, 1988), leaked up the faults over an extended period of time, suggesting not only persistent down-faulting, but also a major upwelling of mantle at this site. This process culminated with emplacement of late granite of the Saint George batholith (Fig. 11f), which according to gravity modelling (Thomas and Willis, in press) is best interpreted as a sheet about $6 \mathrm{~km}$ thick, beneath which both the Paleozoic supracrustal section and probable Precambrian basement extend far to the northwest.

Carboniferous deformation (Fig. 11g) in the context of the Avalon block was entirely superficial, as were effects of the tensional break-up during Triassic opening of the Bay of Fundy (Fig. 11h).

\section{DISCUSSION}

Most penetrative deformation of the western Caledonia block appears to be of Late Precambrian or Carboniferous age. Major deformation of Late Precambrian age occurred in three distinct pulses. The oldest seems to have been an abortive spreading episode about $780 \mathrm{Ma}$. Subduction-related magmatism of unknown polarity occurred about $620 \mathrm{Ma}$. Stratigraphic considerations and isotopic dating suggest that latest Precambrian shearing and plutonism formed a successor to subduction. This episode ended with dyke emplacement, possibly related to opening of the Iapetus Ocean. The analogy to post-Devonian history of the region is strikingly close. The three-fold division and diverse character of the late Precambrian rocks, which have also been found in other terranes (O'Brien and Knight, 1988) shows that the definition of Avalonian terrane needs to be sharpened.

The western part of the Caledonia block formed a stable crystalline mass lying near sea level from Cambrian to early Silurian time. From early Silurian to Late Devonian the northwestern part of the terrane was flexed and faulted downward, with major uprise of mantle material and magma generation. There is no evidence for regional Ordovician or Devonian penetrative deformation. Taconic/Acadian dichotomy seemsnot so much inadequate as irrelevant in this region. Proven Taconic deformation lies far to the west. Acadian deformation, metamorphism and plutonism affected a deep trough of sedimentary rocks northwest of the Saint George batholith, but had little effect on the crystalline rocks. This relation implies that the batholith occupies a position where the basement became relatively weak, possibly due to thinning, or to break-up by faulting.

The geometry and timing of the basement culmination represented by the Caledonia block resemble those predicted by van Staal (1987) for the "fore-arc" bulge formed by peripheral loading of a slab subducted westward during the Acadian orogeny. Explanations of Avalonian terranes have tended to as-

Fig. 11. Structural cartoons of the development of the western end of the Avalon zone in southern New Brunswick.

1 - Brookville gneiss and other basement rocks; 2 - Green Head Group; 3 - deformed amphibolitic dykes and plutons; 4 - Martinon Formation; 5 Coldbrook Group and correlative plutons; 6 - Kingston complex and correlatives; 7 - Cambro-Ordovician sedimentary rocks; 8 - Silurian strata (Mascarene Group and correlatives); 9 - Peralkaline granite; 10 - Mount Douglas granite; 11 - Carboniferous clastic rocks; 12 - Triassic clastic rocks.

(a) $>800 \mathrm{Ma}$. Shelf sequence (Green Head Group) lies on basement

(b) $760 \mathrm{Ma}$. Tensional break-up, dyking, high heat flow with metamorphism and emplacement of diapiric gneiss

(c) $610 \mathrm{Ma}$. Arc magmatism, eruption of the Coldbrook Group and emplacement of large calc-alkaline plutons

(d) $560 \mathrm{Ma}$. Mylonitization due to oblique closure followed by transtension, dyking and minor plutons

(c) $430 \mathrm{Ma}$. After shallow water clastic sedimentation during Cambro-Ordovician, faulting and bimodal magmatism begins

(f) $360 \mathrm{Ma}$. Major granite emplacement, end of down-faulting and flexing

(g) $320 \mathrm{Ma}$. Carboniferous overthrusting affects the Avalonian terrane only superficially

(h) $200 \mathrm{Ma}$. Triassic tensional break-up, sedimentation has only minor effect within the Avalonian terrane 


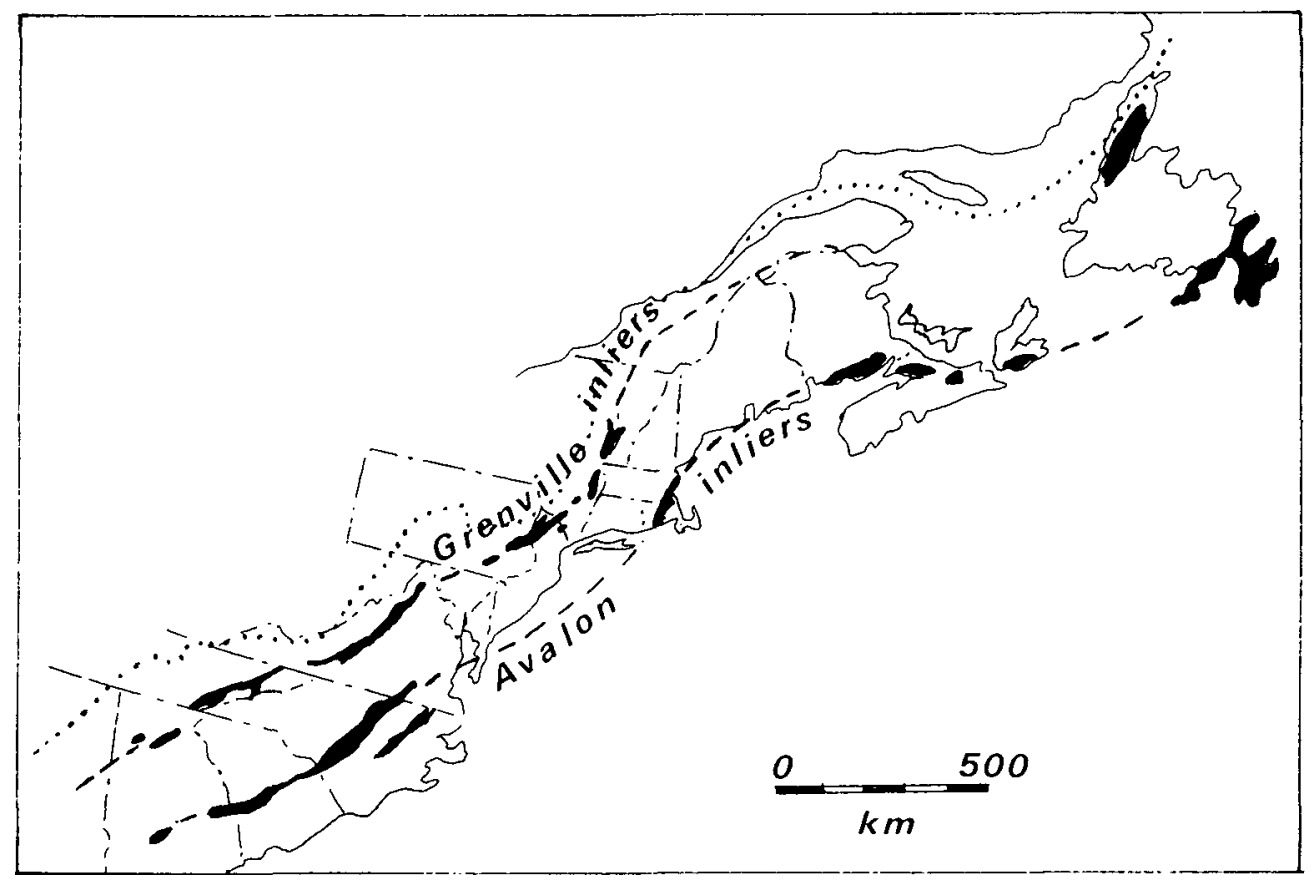

Fig. 12. Major basement inliers in the northem Appalachians. Inliers shown in solid black. Broken lines show trend of Grenville and Avalon inliers. Dash-dot lines show political boundaries. Dotted line marks the edge of the Appalachian orogen. Note the approximately symmetrical disposition of Avalon and Grenville inliers. The plot of Grenville inliers is from Hatcher (1983).

sume, implicitly or explicitly, sharp boundaries, and little extension beyond their known exposure (compare Williams and Hatcher 1983; Keppie, 1984; O’Brien et al., 1983). However evidence is steadily accumulating for a much wider distribution of Avalonian rocks in the sub-surface. Gravity data by Thomas and Willis (in press) suggest the southem New Brunswick Avalonian terrane could extend many kilometres to the northwest of its cxposed edge. Both stable isotope (Bevier, 1988) and detailed age dating evidence (Roddick and Bevier, 1988) suggest Avalonian basement to the Miramichi highland of New Brunswick. In Cape Breton Island, Jamieson et al. (1986) showed that the characteristic three-fold division of Avalonian igneous activity continued from the classic Avalon terrane of the southeast across the metamorphic and plutonic rocks of the western highlands. Avalonian ages and lithologies have been found on the south coast of Newfoundland (Dunning et al., 1988) and "PanAfrican" ages occur in western Newfoundland in transported sliccs (Williams et al., 1985; van Berkel and Currie, 1988). A reasonable case can now be made that Avalonian basement cxtends, perhaps discontinuously, from its surface exposure northwest to the Iapetus suture, although this basement must be hctcrogeneous across strike as a result of Taconian and older plate tectonic process, and considerably modified in regions like western Cape Breton Island and northeastern Maine where it was affected by extensive subsequent plutonism and metamorphism. On this model, exposed Avalonian terranes represent an uplifted wclt of basement, analagous to the chain of Grenvillian terranes on the west side of the Appalachians (Hatcher, 1983). The symmetry of these two types of Precambrian inlier is quite striking (Fig. 12). Once again the insight of Williams (1964) that the Appalachians form a symmetrical two-sided system has proved remarkably prescient.

\section{ACKNOWLEDGEMENTS}

Mike Thomas permitted me to quote results of his gravity survey prior to publication. Mary Lou Bevier made available isotopic data, and Nelson Eby provided chemical data. Ideas have been discussed with Cees van Staal, and with many current and past researchers in southern New Brunswick geology, most of whom disagree with some or all of the concepts presented. Hopefully the clash of ideas will clarify the geology of southern New Brunswick which remains imperfectly understood after 150 years of research. I am indebted to S.R. McCutcheon and N. Rast for careful critical reading of the manuscript.

ALCOCK, F.J. and PERRY, S.C. 1960. Saint George map-area, New Brunswick. Geological Survey of Canada, Map 1094A.

BARR, S.M., RAESIDE, R.P. and VAN BREEMEN, O. 1987. Grenvillian basement in the northem Cape Breton Highlands, Nova Scotia. Canadian Joumal of Earth Sciences, 24, pp. 992-997.

BEVIER, M.L. 1988. Lead isotopic evidence for distinct sources of granite and for distinct basements in the northern Appalachians New Brunswick. Geological Association of Canada, Abstracts with Program, 13.

BROWN, R.L. 1972. Appalachian structural style in southern New Brunswick. Canadian Joumal of Earth Sciences, 9, pp. 43-53.

CAUDILL, M.R. and NANCE, R.D. 1986. Variscan tectonostratigraphy of the Mispec Group, southern New Brunswick; stratigraphy and depositional setting. Geological Survey of Canada, Paper 861A, pp. 343-350.

CURRIE, K.L. 1984. A reconsideration of some geological relations near St. John, New Brunswick. Geological Survey of Canada, Paper 84-1A, pp. 193-201.

. 1986. The stratigraphy and structure of the Avalonian terrane around Saint John, New Brunswick. Maritime Sediments and 
Atlantic Geology, 22, pp. 278-295.

. 1987. Late Precambrian igneous activity in the MusquashLoch Alva region, southern New Brunswick and its tectonic significance. Geological Survey of Canada, Paper 87-1 A.

- 1988. Saint George map-area; the end of the Avalon zone in southem New Brunswick. Geological Survey of Canada, Paper 881B, pp. 9-16.

CURRIE, K.L. and NANCE, R.D. 1983. A reconsideration of the Carboniferous rocks of Saint John, New Brunswick. Geological Survey of Canada, Paper 83-1A, pp. 29-36.

CURRIE, K.L., NANCE, R.D., PAJARI, G.E., and PICKERILL, R.K. 1981. A reconsideration of the pre-Carboniferous geology of Saint John, New Brunswick. Geological Survey of Canada, Paper 811A, pp. 23-30.

DONOHOE, H.V. 1978. Analysis of structures in the Saint George area Charlotte County, New Brunswick. Unpublished Ph.D. thesis, University of New Brunswick, Fredericton, New Brunswick.

DUNNING, G.R., KROGH, T.E., O'BRIEN, S.J., COLMAN-SADD, S.P., and O'NEILL, P. 1988. Geochronologic framework for the central mobile belt in southern Newfoundland and the importance of Silurian orogeny. Geological Association of Canada, Program with Abstracts, 13, p. A34.

GARNETT, J.A. 1973. Structural analysis of part of the LubecBelleisle fault zone, southwestem New Brunswick. Unpublished Ph.D. thesis, University of New Brunswick, Fredericton, New Brunswick.

GARNETT, J.A. and BROWN, R.L. 1973. Fabric variations in the Lubec-Belleisle zone of southem New Brunswick. Canadian Journal of Earth Sciences, 10, pp. 1591-1599.

GAUDETTE, H.E., OLSZEWSKI, W.J., and DONOHOE, H.V. 1983. Age and origin of basement rocks, Cobequid Highlands, Nova Scotia. Geological Society of America, Abstracts with Program, 15, p. 136.

GAUDETTE, H.E., OLSZEWSKI, W.J., and JAMIESON, R.A. 1985. $\mathrm{Rb}$-Sr ages of some basement rocks, Cape Breton Highlands, Nova Scotia. Geological Association of Canada, Program with Abstracts, 10, p. A17.

GUPTA, V.K. 1975. An interpretation of aeromagnetic and gravity data of the Caledonia area in southern New Brunswick. Unpublished Ph.D. thesis, University of New Brunswick, Fredericton, New Brunswick.

HATCHER, R.D. 1983. Basement massifs in the Appalachians; their role in deformation during the Appalachian orogenies. Geological Journal, 18, pp. 255-265.

HAYES, A.D. and HOWELL, B.F. 1937. The geology of Saint John, New Brunswick. Geological Society of America, Special Paper 5.

HELMSTAEDT, H. 1968. Structural analysis of the Beaver Harbour area Charlotte County, New Brunswick. Unpublished Ph.D. thesis, University of New Brunswick, Fredericton, New Brunswick.

HOFMANN, H.J. 1974. The stromatolite Archaeozoon acadiense from the Proterozoic Green Head Group of Saint John, New Brunswick. Canadian Journal of Earth Sciences, 11, pp. 1098-1115.

JAMIESON, R.A. 1984. Low pressure cordierite-bearing migmatites from Kelly's Mountain, Nova Scotia. Contributions to Mineralogy and Petrology, 86, pp. 309-320.

JAMIESON, R.A., VAN BREEMEN, O., SULLIVAN, R.W., and CURRIE, K.L. 1986. The age of igneous and metamorphic events in the westem Cape Breton Highlands, Nova Scotia. Canadian Journal of Earth Sciences, 23, pp. 1891-1901.

KEPPIE, J.D. 1984. The Appalachian collage. In The Caledonide Orogen, Scandanavia and related areas. Edited by D.G. Gee and B.
Sturt. John Wiley and Sons, New York.

KROGH, T.E., STRONG, D.F., and PAPEZIK, V.S. 1988. Precise Pb$\mathrm{U}$ dates from the Avalon Terrane in Newfoundland. Canadian Journal of Earth Sciences, 25, pp. 442-453.

LEGER, A. 1986. Transcurrent faulting history of southem New Brunswick. Unpublished M.Sc. thesis, University of New Brunswick, Fredericton, New Brunswick.

McLEOD, M.J. 1987. Saint George batholith project (east). New Brunswick Department of Natural Resources and Energy, Minerals and Energy Division Information Circular, 87-2, pp. 33-36.

McCUTCHEON, S.R. and BOUCOT, A.J. 1984. A new Lower Silurian fossil locality in the northeastem Mascarene-Nerepis belt, southern New Brunswick. Maritime Sediments and Atlantic Geology, 20, pp. 121-126.

McCUTCHEON, S.R. and RUITENBERG, A.A. 1987. Geology' and mineral deposits Annidale-Nerepis area New Brunswick. New Brunswick Department of Natural Resources and Energy, Mineral Development Division, Memoir 2.

NANCE, R.D. 1982. Structural reconnaisance of the Green Head Group, Saint John, New Brunswick. Geological Survey of Canada, Paper 82-1A, pp. 37-43.

NANCE, R.D. and WARNER, J.B. 1986. Variscan tectonostratigraphy of the Mispec Group; structural geometry and deformation history. Geological Survey of Canada, Paper 86-1A, pp. 351-358.

O'BRIEN, B.H. 1976. The geology of parts of the Coldbrook Group. southem New Brunswick. Unpublished M.Sc. thesis, University of New Brunswick, Fredericton, New Brunswick.

O'BRIEN, S.J. and KNIGHT, I. 1988. The Avalonian geology of southwest Bonavista Bay: portions of the St.Brendans $(2 \mathrm{C} / 13)$ and Eastport (2C/12) map areas. Newfoundland Department of Mines. Mineral Development Division, Report 88-1, pp. 193-205.

O'BRIEN, S.J., WARDLE, R.J., and KING, A.F. 1983. The Avalon zone: a Pan-African terrane in the Appalachian orogen of Canada. Geological Joumal, 18, pp. 198-222.

OLSZEWSKI, W.J. and GAUDETTE, H.E. 1982. Age of the Brookville gneiss and associated rocks, southeastern New Brunswick. Canadian Journal of Earth Sciences, 19, pp. 2158-2166.

OLSZEWSKI, W.J., GAUDETTE, H.E., and POOLE, W.H. 1980. Rb$\mathrm{Sr}$ whole rock and $\mathrm{U}-\mathrm{Pb}$ zircon ages from the Green Head Group. New Brunswick. Geological Society of America, Abstracts with Progam, 12, p. 76.

PARKER, J.S.D. 1984. Geological relationships of basement to cover Musquash Harbour to Black River, Saint John area, southem New Brunswick. Unpublished M.Sc. thesis, University of New Brunswick, Fredericton, New Brunswick.

PAYETTE, C. and MARTIN, R.F. 1987. The Welsford igneous complex, southem New Brunswick, rift-related Acadian magmatism. Geological Survey of Canada, Paper 87-1A, pp. 239-248.

PICKERILL, R.K., PAJARI, G.E., and DICKSON, W.L. 1978. Geology of the Lower Devonian rocks of Passamaquoddy Bay, Southwest New Brunswick. In Guidebook for field trips in southeastern Maine and Southwestern New Brunswick. Edited by A. Ludman. Queens College Press Geological Bulletin, 6, pp. 38-56.

RAST, N. 1979. Precambrian meta-diabases of southem New Brunswick - the opening of the Iapetus Ocean? Tectonophysics, 59, pp. 127-137.

RAST, N. and CURRIE, K.L. 1976. On the position of the Variscan front in southem New Brunswick and its relation to Precambriam basement. Canadian Joumal of Earth Sciences, 13, pp. 194-196.

RAST. N. and DICKSON, W.L. 1982. The Pocologan Mylonite zone. Geological Association of Canada, Special Paper 24, pp. 249-261. RAST, N. and GRANT, R.H. 1974. Trans-Atlantic correlation of the 
Variscan-Appalachian orogeny. American Joumal of Science, 273, pp. 572-579.

RAST, N., O'BRIEN, B.H., and WARDLE, R.J. 1976. Relationhips between the Precambrian and Lower Paleozoic rocks of the Avalon Platform in New Brunswick, the northeastern Appalachians and the British Isles. Tectonophysics, 30, pp. 315-338.

RAST, N., GRANT, R.H., PARKER, J.S.D., and TENG, H.C. 1978. The Carboniferous deformed rocks west of Saint John, New Brunswick. Queens College Press Geological Bulletin, 6.

RODDICK, J.C. and BEVIER, M.L. 1988. Conventional and ion microprobe U-Pb ages of two Paleozoic granites, Miramichi terrane, New Brunswick. Geological Association of Canada, Abstracts with Program, 13.

RUITENBERG, A.A. 1969. Mineral deposits in granitic intrusions and related metamorphic aureoles in parts of the Welsford, Loch Alva, Musquash and Pennfield areas. Department of Natural Resources, Mineral Resources Branch Report of Investigation, 9.

RUITENBERG, A.A. and McCUTCHEON, S.R. 1982. Acadian and Hercynian structural evolution of southem New Brunswick. Geological Association Canada, Special Paper 24, pp. 131-148.

RUITENBERG, A.A., VENUGOPAL, D.V., and GILES, P.S. 1973. Fundy cataclastic zone, New Brunswick; evidence for post-Acadian penetrative deformation. Geological Society of America Bulletin, 84, pp. 3029-3044.

RUITENBERG, A.A., GILES, P.S., VENUGOPAL, D.V., BUTTIMER, S.M., McCUTCHEON, S.R., and CHANDRA, J. 1979. Geology and mineral deposits Caledonia area. New Brunswick Department of Natural Resources, Mineral Resources Branch, Memoir 1.

RUITENBERG, A.A., FYFFE, L.R., McCUTCHEON, S.R., St. PETER, C.J., IRRINKI, R.R., and VENUGOPAL, D.V. 1977. Evolution of the pre-Carboniferous tectonostratigraphic zones in the New Brunswick Appalachians. Geoscience Canada, 4, pp. 171 181.

SCHLUGER, P.R. 1973. Stratigraphy and sedimentary environments of the Devonian Perry Formation, New Brunswick, Canada and Maine, U.S.A. Geological Society of America Bulletin, 84, pp. 2533-2548.

SHIVES, R. 1986. Airborne gamma ray spectrometric surveys, \%K. Saint John (west half). Geological Survey of Canada Map $35721(8) \mathrm{G}$.

SPECTOR, A. and PICHETTE, R.J. 1980. Report on aeromagnetic interpretation of New Brunswick Carboniferous basins. New Brunswick Department of Natural Resources, Open File Report 80-8, 31 p.

STRINGER, P. 1982. Deformation of Ordovician and Silurian rocks at Oak Bay and Cookson Island, St. Stephen, New Brunswick. Journal of Structural Geology, 4, pp. 234-235.

STRONG, D.F. and DOSTAL, J. 1980. Dyanamic melting of Proterozoic upper mantle: evidence from rare earth elements in oceanic crust of eastern Newfoundland. Contributions to Mineralogy and Petrology, 72, pp. 165-173.

STUKAS, V. 1978. Plagioclase release patterns: a high resolution ${ }^{40} \mathrm{Ar} /$ ${ }^{39} \mathrm{Ar}$ study. Unpublished Ph.D. thesis, Dalhousie University, Halifax, Nova Scotia.

TANOLI, S.K. 1987. Stratigraphy, sedimentology and ichnology of the Cambrian-Ordovician Saint John Group, southem New Brunswick, Canada. Unpublished Ph.D. thesis, University of New Brunswick, Fredericton, New Brunswick.

THOMAS, M.D. and WILLIS, C. In press. Gravity models of the Saint George batholith, New Brunswick Appalachians. Canadian Journal of Earth Sciences.

VAN BERKEL, J.T. and CURRIE, K.L. 1988. Geology of the Puddlc Pond and Little Grand Lake map areas, southwestem Newfoundland. Newfoundland Department of Mines, Mineral Development Division, Report 88-1, pp. 99-107.

VAN STAAL, C.R. 1987. Tectonic setting of the Tetagouche Group in northem New Brunswick: implications for plate tectonic models of the northem Appalachians. Canadian Journal of Earth Sciences, 24, pp. 1329-1351.

VAN WAGONER, N.A. and FAYE, V.K. 1988. Stratigraphy and volcanology of a portion of the Lower Devonian volcanic rocks of southwest New Brunswick. Geological Survey of Canada, Paper 88-1A.

WARDLE, R.J. 1977. The stratigraphy and tectonics of the Greenhead Group: its relationship to Hadrynian and Paleozoic rocks, southem New Brunswick. Unpublished Ph.D. thesis, University of New Brunswick, Fredericton, New Brunswick.

WATTERS, S.E. 1987. Gold-bearing rocks - Bay of Fundy coastal zone. Department of Natural Resources and Energy, Minerals and Energy Division Information Circular, 87-2, pp. 41-44.

WILLIAMS, H. 1964. The Appalachians in northeast Newfoundland - a two-sided symmetrical system. American Journal of Science, 262, pp. 1137-1158.

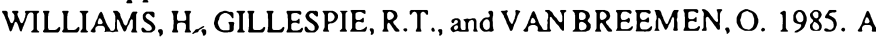
late Precambrian rift-related igneous suite in westem Newfoundland. Canadian Joumal of Earth Sciences, 22, pp. 1727-1735.

WILLIAMS, H. and HATCHER, R.D. 1983. Appalachian suspect terranes. In Contributions to the Tectonics of Mountain Chains. Edited by R.D. Williams and I. Zietz. Geological Society of America, Memoir 158, pp. 33-53.

WOOD, D.A. 1980. The application of the Th-Hf-Ta diagram to problem of tectonomagmatic classification and to establishing the nature of crustal contamination of basaltic lavas of the British tertiary volcanic province. Earth and Planetary Science Letters, 50, pp. 11-30.

WORSLEY, T.R., NANCE, R.D., and MOODY, J.B. 1984. Global tectonics and eustasy for the past 2 billion years. Marine Geology, 58, pp. $373-400$. 